\title{
Assessment of Plant Commnunity Structure in a Tropical Wetland Affected by Brick Making-The Case of Sironga Wetland, Kenya
}

\author{
Caren N. Atalitsa ${ }^{{ }^{*}}{ }^{\oplus}$, George M. Ogendi ${ }^{1,2}$, John M. Mironga ${ }^{3}$, Nicholas Olekaikai ${ }^{4}$ \\ ${ }^{1}$ Department of Environmental Science, Egerton University, Egerton, Kenya \\ ${ }^{2}$ Dryland Research Training and Ecotourism Centre, Egerton University, Egerton, Kenya \\ ${ }^{3}$ Department of Geography, Egerton University, Egerton, Kenya \\ ${ }^{4}$ Department of Natural Resources, Egerton University, Egerton, Kenya \\ Email: *atalitsa@gmail.com, gmorara2009@gmail.com, john.mironga@gmail.com,nolekaikai@yahoo.com
}

How to cite this paper: Atalitsa, C.N., Ogendi, G.M., Mironga, J.M. and Olekaikai, N. (2021) Assessment of Plant Commnunity Structure in a Tropical Wetland Affected by Brick Making-The Case of Sironga Wetland, Kenya. Journal of Environmental Protection, 12, 1001-1008. https://doi.org/10.4236/jep.2021.1211058

Received: October 5, 2021

Accepted: November 27, 2021

Published: November 30, 2021

Copyright $\odot 2021$ by author(s) and Scientific Research Publishing Inc. This work is licensed under the Creative Commons Attribution International License (CC BY 4.0).

http://creativecommons.org/licenses/by/4.0/

\begin{abstract}
Brick making is one of the major small-scale industries in Sironga which has been expanding due to the growing demand for urban expansion. Due to the increasing population pressure, brick-making is competing for the wetland resources. Sironga wetland is threatened with serious degradation and probable loss of plant diversity. Conversion of this wetland for economic uses such as brick making has resulted in its loss. The objective of the study was to assess the effects of brick making on plant diversity in Sironga wetland. Nyamira County, Kenya. A one metre by one metre quadrat frame was laid down and perpendicularly recorded the percent cover for each species found inside the quadrant plus the percentage area covered by the bare ground litter. From each transect lines "diagonally" detailed vegetation under study was then done. The plant species were recorded and classified into three life-forms; herbs, sedges and grasses. The study revealed that grasses had the highest diversity $\mathrm{H}=1.144$. Diversity for herbs was $\mathrm{H}=0.987$ and $\mathrm{H}=0.899$ for reeds respectively. The study concluded that brick-making activities affected the plant diversity in Sironga wetland. This may be attributed partly to the limited information and awareness campaigns to the surrounding communities on the values and benefits of wetland ecosystem services and the lack of alternative livelihood sources. The study recommends that alternative livelihoods are provided and awareness campaigns on the values and benefits of wetlands to the residents are done by the relevant agencies.
\end{abstract}

\section{Keywords}

Diversity Index, Vegetation Types, Environmental Degradation 


\section{Introduction}

Wetlands are habitats for animal and plant communities and have a vital function in maintaining ecosystem balance. The ecological functions of wetlands include maintaining micro-climate and conserving water reservoirs. Humans depend on wetland resources for their livelihood, thereby modifying the community structure of wetland flora and fauna. One of the anthropogenic activities associated with wetlands in developing countries is brick making. Brick making industry is the oldest industry in the history of mankind. Bricks are extensively used as the main input in construction because of their durability, reliability, low cost and easy availability [1]. In Kenya, bricks are still the preferred building material and hence brick making is a lucrative business and many areas are flouted by informal sectors of brick-making activities [2]. In Sironga wetland located in Nyamira County (Western Kenya), bricks are made using traditional kilns. Brick production in the wetland involves cutting of vegetation and draining the area which impacts directly on wetland biodiversity. Brick-making has immense disturbance potential to cause ecological alterations [3]. Disturbance has been recognized as one of the major factors influencing variations in species diversity [4] [5]. Brick-making activities cause significant disturbances on land [6] that adversely affect vegetation [7]. The disturbances alter the physico-chemical properties and habitats of soil which are likely to influence species diversity [3]. Due to the increasing human population, the demand for bricks for housing within and outside the study area has been increasing which poses a threat to the plant species and diversity. Although production of bricks in the study area has risen in the last decade [8], there is insufficient information on the effects of brick making on plant diversity. This study was undertaken to assess the plant community structure following the rise in brick-making activities within Sironga wetland.

\section{Materials and Methods}

\subsection{Study Area}

Sironga wetland is situated in Nyamira sub-location, Western Kenya. It is located at longitudes $34^{\circ} 45^{\prime}$ and $35^{\circ} 00^{\prime}$ East, and latitudes $0^{\circ} 30^{\prime}$ and $0^{\circ} 45^{\prime}$ South. The total area is approximately $899.4 \mathrm{~km}^{2}$ [8]. The study area has two rainy seasons that is well distributed throughout the year with the long rainy season occurring in December to June and short rain seasons from July to November. Annual rainfall ranges between $1200 \mathrm{~mm}-2100 \mathrm{~mm}$ per annum. Daily temperatures range between $28.7^{\circ} \mathrm{C}$ and $10.1^{\circ} \mathrm{C}$ respectively. The average normal temperature is $19.4^{\circ} \mathrm{C}$ which is favorable for both agricultural and livestock production [9]. Sironga wetland is an area where most activities of brick making take place and the volume of bricks produced in this area is the highest compared to other wetlands in the County including the neighbouring Nyabomite, Nyabioto and Charachani wetlands. 


\subsection{Sampling and Data Analysis}

An ecological survey study design was adopted in this study. Vegetation foliar cover was determined using the quadrat method. The centre of the study area was established, after which four transect lines were laid down from the centre of the study area. Random quadrat method was used to conduct vegetation sampling where measurement of species composition was carried out. The plot size measured $800 \mathrm{~m}$ by $600 \mathrm{~m}$. The exercise was repeated for 15 quadrats. Inside each plot, quadrats of sizes $1 \mathrm{~m}$ by $1 \mathrm{~m}$ were placed at random. In each plot, all species of plants were identified and recorded, and their percentage cover estimated. The Plant species within the plots were recorded and classified into three life-forms; herbs, sedges and grasses. The species diversity was calculated using the standard diversity index; Shannon diversity index $H$.

$$
\text { Shannon Index }(H)=\sum_{i=1}^{s} P_{i} \ln P_{i}
$$

where $P_{i}=N_{i} / N$;

$$
\begin{aligned}
& \text { And } N_{i}=\text { Sum of individual of a species; } \\
& N=\text { Sum of overall species. }
\end{aligned}
$$

\section{Results and Discussion}

Table 1 shows the plant species that were identified in Sironga wetland during the study. The plants were classified into herbs, sedges/reeds and grasses. A total of 39 plant species were identified: 24 herbs, 8 sedges and 7 grasses. The results showed that the family of Asteraceae had the highest number of 8 plant species each followed by Acanthaceae with 3 plant species each, Papilionaceae with 2 plant species each and Oxilidaceae, Brassicaceae, Caryophyllaceae, Commelinaceae, Menispermaceae, Lamiaceae, Apocynaceae, Cucurbitaceae, Dernstaedtiaceae, Caesalpiniaceae with 1 plant species each.

The Shannon entropy index analysis revealed that species diversity for herbs in Sironga Wetland was $0.987,0.899$ and 1.144 for herbs, sedges and grasses respectively. The diversity of all the plant species showed that grasses had the highest diversity followed by herbs and reeds respectively. The dominance of the grasses is assumed to be high because it is fast growing aquatic species of the wetland and therefore when trees/shrubs are cut, the grasses take over fast. Sedges and grasses are also the main peat formers in wetland environments [10] [11] hence dominating the wetland. Though there are some dominant species in Sironga wetland for example Scirpus debilis with 10,998 individuals and Ipomoea acquatica with 9802 individuals, the diversity is still low. The presence of several species in a disturbed environment is because the species have the ability to live and adapt to the environmental changes [12]. The main causes of biodiversity loss are land use and land cover changes which may lead to the dominance of new invasive species at the expense of native plant species [13] [14]. This supports the findings that the low number of species in Sironga is due to disruption of the ecosystem by activities such as brick making. This supports the 
Table 1. Plant diversity in Sironga wetland.

\begin{tabular}{|c|c|c|c|c|c|c|c|}
\hline No & Order & Family & Species & $\begin{array}{c}\text { No. } \\
\text { Counted }\end{array}$ & $P_{i}$ & $\ln P_{i}$ & $P_{i}^{\star} \ln P_{i}$ \\
\hline \multicolumn{8}{|c|}{ HERBS } \\
\hline 1 & Asterales & Asteraceae & Aspillia spp. & 1 & 0.00008 & -9.433 & -0.001 \\
\hline 2 & Asterales & Asteraceae & Spilanthes mauritania & 1 & 0.00008 & -9.433 & -0.001 \\
\hline 3 & Asterales/compositales & Asteraceae & Sphaeraranthus spp. & 1 & 0.00008 & -9.433 & -0.001 \\
\hline 4 & Asterales/compositales & Asteraceae & Senecio spp. & 59 & 0.00457 & -5.388 & -0.025 \\
\hline 5 & Asterales/compositales & Asteraceae & Conyza bonariense & 5 & 0.00039 & -7.849 & -0.003 \\
\hline 6 & Asterales/compositales & Asteraceae & Blepharis integrifolia & 1 & 0.00008 & -9.433 & -0.001 \\
\hline 7 & Asterales/compositales & Asteraceae & Dichondra repens & 1107 & 0.08579 & -2.456 & -0.211 \\
\hline 8 & Asterales/compositales & Asteraceae & Ageratum spp. & 74 & 0.00573 & -5.162 & -0.030 \\
\hline 9 & Caryophyllales & Caryophyllaceae & Silene garlica & 7 & 0.00054 & -7.524 & -0.004 \\
\hline 10 & Commelinales & Commelinaceae & Commelina benghalensis & 3 & 0.00023 & -8.377 & -0.002 \\
\hline 11 & Cruciferales & Brassicaceae & Brassica napus & 2 & 0.00015 & -8.805 & -0.001 \\
\hline 12 & Cucurbitales & Cucurbitaceae & Momordica foetida & 1 & 0.00008 & -9.433 & -0.001 \\
\hline 13 & Fabales & Papilionaceae & Trifolium semi-pilosum & 723 & 0.05603 & -2.882 & -0.161 \\
\hline 14 & Fabales & Papilionaceae & Dolichus spp. & 543 & 0.04208 & -3.168 & -0.133 \\
\hline 15 & Fabales & Caesalpiniaceae & Cassia didymobtrya & 8 & 0.00062 & -7.386 & -0.005 \\
\hline 16 & Gentianales & Apocynaceae & Catharantus roseus & 3 & 0.00023 & -8.377 & -0.002 \\
\hline 17 & Geraniales & Oxilidaceae & Oxalis latifolia & 203 & 0.01573 & -4.152 & -0.065 \\
\hline 18 & Lamiales & Acanthaceae & Hypoestes forskabili & 46 & 0.00356 & -5.638 & -0.020 \\
\hline 19 & Lamiales & Acanthaceae & Hypoestes spp. & 200 & 0.01550 & -4.167 & -0.065 \\
\hline 20 & Lamiales & Lamiaceae & Fuerstia africana & 6 & 0.00046 & -7.684 & -0.004 \\
\hline 21 & Lamiales & Acanthaceae & Thunbergia annua & 1 & 0.00008 & -9.433 & -0.001 \\
\hline 22 & Polypodiales & Dernstaedtiaceae & Pteridium aquilinum & 1 & 0.00008 & -9.433 & -0.001 \\
\hline 23 & Ranunculales & Menispermaceae & Cissampelos pareira & 106 & 0.00821 & -4.802 & -0.040 \\
\hline \multirow[t]{3}{*}{24} & \multirow[t]{3}{*}{ Solanales } & Convolvulacea & Ipomoea acquatica & 9802 & 0.75961 & -0.275 & -0.209 \\
\hline & & & Total & 12,904 & & & -0.987 \\
\hline & & & & \multicolumn{3}{|c|}{$H=-\sum_{1}^{24} P_{i} \ln P_{i}$} & 0.987 \\
\hline & & & Sedges: Cyperaceae & & & & \\
\hline 25 & Poales & & Scirpus debilis & 10998 & 0.74939 & -0.288 & -0.216 \\
\hline 26 & Poales & & Cyperus digitatus & 196 & 0.01336 & -4.315 & -0.058 \\
\hline 27 & Poales & & Kyallinga spp. & 176 & 0.01199 & -4.431 & -0.053 \\
\hline 28 & Poales & & Cyperus esculentus & 486 & 0.03312 & -3.408 & -0.113 \\
\hline 29 & Poales & & Cyperus spp. & 78 & 0.00531 & -5.238 & -0.028 \\
\hline 30 & Poales & & Cyperus rigidifolia & 739 & 0.05035 & -2.989 & -0.150 \\
\hline
\end{tabular}




\begin{tabular}{|c|c|c|c|c|c|c|}
\hline 31 & Poales & Carex spp. & 1979 & 0.13485 & -2.004 & -0.270 \\
\hline \multirow[t]{3}{*}{32} & Poales & Cyperus rotundus & 24 & 0.00164 & -6.413 & -0.011 \\
\hline & & Total & 14676 & & & -0.899 \\
\hline & & & \multicolumn{3}{|c|}{$\begin{array}{l}\text { Shannon entropy index } \\
\qquad H=-\sum_{1}^{8} P_{i} \ln P_{i}\end{array}$} & 0.899 \\
\hline \multicolumn{7}{|c|}{ Grasses: Poaceae/Graminae } \\
\hline 33 & Poales & $\begin{array}{l}\text { Pennisetum } \\
\text { clandestinum }\end{array}$ & 780 & 0.15479 & -1.866 & -0.288 \\
\hline 34 & Poales & Digitaria scalarum & 3228 & 0.64060 & -0.445 & -0.285 \\
\hline 35 & Poales & Digitaria velutina & 230 & 0.04564 & -3.087 & -0.141 \\
\hline 36 & Poales & Sporobulus pyramidalis & 30 & 0.00595 & -5.124 & -0.030 \\
\hline 37 & Poales & Paspalum spp. & 573 & 0.11371 & -2.174 & -0.247 \\
\hline 38 & Poales & Eragrostis ciliaensis & 129 & 0.02560 & -3.665 & -0.094 \\
\hline \multirow[t]{3}{*}{39} & Poales & Eragrostis racemosa & 69 & 0.01369 & -4.291 & -0.059 \\
\hline & & Totals & 5039 & & & -1.144 \\
\hline & & & \multicolumn{3}{|c|}{$H=-\sum_{1}^{7} P_{i} \ln P_{i}$} & 1.144 \\
\hline
\end{tabular}

findings that the low number of species in Sironga is due to disruption of the ecosystem by activities such as brick-making, human settlement and deforestation. It implies that Sironga wetland has been degraded as a result of unsustainable exploitation which has affected the diversity of the plant species. Brick-making has led to the destruction of the habitat for both fauna and flora affecting species abundance and species diversity. It can therefore be deduced that the extraction of resources from Sironga wetland has led to low species diversity.

Cyperus spp. was a source of building materials for traditional houses, so was clay. However, with the reduction of grass, it has led to decrease in traditional grass thatched houses. The introduction of brick-making also saw a shift in building materials. Many people started changing from traditional houses made of clay to brick houses. The reduction of Cyperus spp. also saw a shift to iron sheets for roofing. Since the inception of brick making in the wetland, reduction of Cyperus spp. can be explained by the high demand for the grass to cover the bricks from the effects of direct sunlight, rain and destruction from livestock. A report by [8], made a similar observation of Cyperus spp. used to cover bricks when they are spread out to dry to avoid destruction from cattle, sunlight and rainfall. According to [15], a major consumptive practice in Sironga leading to the diminishing of papyrus was due to its multiple usage in building traditional houses and rampant brick making. Habitat alteration/destruction or loss is the greatest threat to plant species. As human population undertake brick-making 
activities in the wetland, there is disturbance or alteration and loss of many habitats for wild species. Deforestation, draining and reclaiming wetlands and mowing fields for residential or commercial purposes, human settlement, mining are predominant elements of habitat fragmentation which affects species diversity leading habitat destruction [16]. These activities destroy habitats for plants and animal species, isolate communities, therefore, compressing genetic diversity [17]. In Sironga wetland, a number of plant species have declined and may become extinct in the near future. For instance, plant species for Asteraceae Lamiaceae and Solanaceae are 8, 1, and 1 each respectively. There is a probability of the decline has been affected by harvesting of Cyperus spp. and brick making. Findings of this study in relation with other wetlands regionally and internationally, demonstrate that extensive brick making poses a danger of some plants species going into extinction unless measures are taken to preserve the wetland. Despite the fact that very few wetlands are found within Nyamira County, brick making as an economic activity influences plant diversity. The study revealed that brick making in Sironga wetland has contributed to the decline in plant diversity. Low diversity index could also be contributed by other factors such as planting Eucalyptus Saligna which contributes to both wetland drainage, which reduces diversity of plants, and loss of plant species. Studies have shown that Eucalyptus trees exclude most under growths reducing flora in situ. From the study, it is concluded that encroachment on Sironga wetland through brick making has contributed to the loss of biodiversity. Conservation practices such as use of locally adapted and indigenous tree seedlings should be encouraged so as to sustain the wetland. Grounds, where the production of bricks takes place, should be refilled by planting the suitable tree species to make the ground more stable. Planting bamboo trees should also be encouraged to meet the energy requirements for brick production. Enrichment planting should be carried out for ecological restoration of the degraded area. The Ministry of Environment, Water, Energy, Mining and Natural Resources, NEMA, Forestry Department and the County Government should work together with the County Government and Survey of Kenya Institute of Survey and Mapping to monitor wetlands overtime since it is important to assess its functioning and maintaining the wetland.

\section{Conclusion}

Encroachment on Sironga wetland through brick making and planting of Eucalyptus trees had contributed to the loss of biodiversity. Lack of adequate and appropriate knowledge about the functions and values of wetlands has hindered active management by local communities. The existing policies and legislations on wetlands and strategies aimed at enhancing the wetland functions and values and protecting biodiversity have not been met.

\section{Acknowledgements}

The authors are grateful to Egerton University, for according us the opportunity 
to do this study.

\section{Conflicts of Interest}

The authors declare no conflict of interest.

\section{References}

[1] Naveen, S. (2016) Production and Marketing Network Chain of Brick Kiln Product. A Case Study of Hyderabad City. International Journal of Managing Value and Supply Chain, 7, 27-37.

[2] Mareri, O.R. (1993) The Role of Small-Scale Brick Producers and the Use of Bricks in Rural Housing. Master's Thesis, University of Nairobi, Nairobi.

[3] Gupta, S. and Narayan, R. (2010) Brick Kiln Industry in Long-Term Impacts Biomass and Diversity Structure of Plant Communities. Current Science, 99, 72-79.

[4] Connell, J.H. (1978) Diversity in Tropical Rain Forests and Coral Reefs. Science, 199, 1302-1310. https://doi.org/10.1126/science.199.4335.1302

[5] Noss, R.S. (1996) Conservation of Biodiversity at the Landscape Scale. In: Szaro, R.C. and Johnston, D.W., Eds., Biodiversity in Managed Landscapes. Theory and Practice, Oxford University Press, New York, 574-589.

[6] Asgher, S. (2004) Land Degradation and Environmental Pollution: Impact of Brick Kilns. BR Publishing Corporation, New Delhi.

[7] Bhanarkar, A.D., Gajghate, D.G. and Hasan, M.Z. (2002) Assessment of Air Pollution from Small Scale Industry. Environmental Monitoring and Assessment, 80, 125-133. https://doi.org/10.1023/A:1020636930033

[8] Masese, J.B. (1997) The Implication of Human Perception on the Conservation of Sironga and Kianginda Wetlands in Kenya. Master's Thesis, Kenyatta University, Nairobi.

[9] Government of Kenya (2013) First Nyamira County Integrated Development Plan (CIDP)-2013-2017. County Government of Nyamira, Nyamira.

[10] Johnson, D., Kershaw, L., MacKinnon A. and Pojar, J. (1995) Plants of the Western Boreal Forest and Aspen Parkland. Lone Pine Publishing, Edmonton.

[11] Tande, G.F. and Lipkin, R. (2003) Wetland Sedges of Alaska. Natural Heritage Program, Environment and Natural Resources Institute, University of Alaska, Anchorage.

[12] Akram, H., Pasaribu, N. and Siregar, E.S. (2019) Tree Species Diversity, Richness and Similarity in Disturbed and Undisturbed Forest of Ketambe Research Station, South East Aceh Regency. IOP Conference Series. Earth and Environment Science, 305, Article ID: 012094. https://doi.org/10.1088/1755-1315/305/1/012094

[13] Saha, S. (2001) Comparison of Vegetation Structure and Composition between Secondary Deciduous Forests and Tectona grandis (Teak, Family Verbanaceae) Plantations in Bori Wildlife Sanctuary of Central India. Forest Ecology and Management, 148, 159-167. https://doi.org/10.1016/S0378-1127(00)00533-8

[14] Kibet, K.R., Olatubara, C.O., Ikporukpo, C.O. and Jebiwott, A. (2021) Land Use Land Cover Changes and Encroachment Issues in Kapkatet Wetland, Kenya. Open Journal of Ecology, 11, 493-506. https://doi.org/10.4236/oje.2021.117032

[15] Nyaboga, J.O., Angawa, F. and Huho, J.M. (2015) Sustainable Utilization of Wetland Resources in Selected Areas of Nyamira County. Geography, 2, 2349-5367.

[16] Singh, V., Shukla, S. and Singh, A. (2021) The Principal Factors Responsible for 
Biodiversity Loss. Open Journal of Plant Science, 6, 11-14.

[17] Bright, P.W. (1993) Habitat Fragmentation-Problems and Predictions for British Mammals. Mammal Review, 23, 101-111.

https://doi.org/10.1111/j.1365-2907.1993.tb00420.x 